\title{
Proceeding
}

Supplementary Issue: Winter Conferences of Sports Science. Costa Blanca Sports Science Events, 25-26 January 2019.

Alicante, Spain

\section{Preliminary work about the basis data for monitoring youth soccer team planning training}

\author{
ROSARIO CERUSO ${ }^{1} \unlhd$, GIOVANNI ESPOSITO ${ }^{1}$, ARIO FEDERICl ${ }^{2}$, MANUELA VALENTINI ${ }^{2}$, TIZIANA \\ D'ISANTO1 \\ 1 University of Salerno, Italy \\ 2University of Carlo Bo of Urbino, Italy
}

\begin{abstract}
The youth soccer is always important especially for the assessment and the data of development of skills. The monitoring of them it could be important for the trainer to reorganize the planning of training and for the adaptation to individual athlete Aim of the study is to recruit the quantitative data about the anthropometric and performance aspects for reutilize to rearrangement of training planning. Method is experimental and has to carry out the usual parameters for monitoring the trainings. Anthropometric data are weight, height, BMI and performance data are Vo2max (Cooper) speed triangle test (three corner run) and speed test with (dribbling) on a sample are 13 athletes of 13 years old that play championship under 14 . BMI Data shows 6 weight, 4 in overweight risk and 3 in overweight. Cooper test data shows 2 above- average, 5 average, 5 below average and 1 poor. Mean speed triangle test 32.38 seconds, mean dibbling test 25.39 seconds. The results have to be useful for tool method of training. Key words: Cooper test; BMl; Dribbling test; Threecorner runner test.
\end{abstract}

\section{Cite this article as:}

Ceruso, R., Esposito, G., Federici, A., Valentini, M., \& D'Isanto, T. (2019). Preliminary work about the basis data for monitoring youth soccer team planning training. Journal of Human Sport and Exercise, 14(2proc), S251-S257. doi:https://doi.org/10.14198/jhse.2019.14.Proc2.14

\section{Corresponding author. University of Salerno, Italy.}

E-mail: r.ceruso2@studenti.unisa.it

Supplementary Issue: Winter Conferences of Sports Science. Costa Blanca Sports Science Events, 25-26 January 2019. Alicante, Spain.

JOURNAL OF HUMAN SPORT \& EXERCISE ISSN 1988-5202

(c) Faculty of Education. University of Alicante.

doi:10.14198/jhse.2019.14.Proc2.14 


\section{INTRODUCTION}

Today young people do little motor activity, so they tend to be overweight, with poor general physical fitness, represented mainly by basic aerobic deficits and from incorrect movement techniques (Pincolini, 2008). Early specialization tends to block motor development; very few become champions; talent is a rare heritage (Myer et al., 2015). In evaluating the results of the tests on young people it must be remembered that some parameters change during growth as a consequence of the variation of body size, while others are the result of qualitative modifications of some physiological functions, which have nothing to do with body size (Bar-Or \& Rowland, 2004).

Starting from these considerations, tests for youth categories are carried out with three main purposes:

- $\quad$ Educate for exercise and evaluation. In fact, everyone struggles to do things for which that are not trained or whose meaning they do not understand. In particular, functional assessment can contribute to education through knowledge of one's own body and above all one's own limits;

- $\quad$ Frame those in front of you. In particular Marella \& Risaliti (2007) suggest that a coach who is facing a prepubescent teenager, every two-three months should ask if the size of the young footballer, the growth rate and body appearance are limited by age, sex, population and socio-economic group;

- $\quad$ Prevent injuries.

For youth categories, we mean all those involving players under the age of eighteen. Within these we can distinguish young athletes in prepuberal age, from those who have overcome puberty, remembering that between these two categories fits the period of puberty, which involves important somatopsychic modifications. (D'Isanto, T., D'elia, F., Raiola, G., Altavilla, G. 2019).

Not only does the start time of puberty vary from child to child, but also the effects of puberty on the football qualities of the players are very different. Furthermore, it is necessary to keep in mind those that Jurgen Baur defined as sensitive phases, or those periods in the life of a young person in whom very specific behavioural patterns related to the environment are quickly acquired and in which there is a high sensitivity of the organism towards certain experiences (Baur, 1993).

The functional evaluation of young people is essentially based on field tests, relegating those in the laboratory to special cases or special needs (Altavilla, G., Mazzeo, F., D'Elia, F., Raiola, G., 2018). When proposing tests to youth categories it is necessary to understand the following factors: Young people need more time to become familiar with the tests. For the interpretation of the tests, it is necessary to distinguish the influence of the chronological and biological age. The experience of functional assessment tests must be positive and fun for everyone. Physical (but also technical) tests are a unique opportunity to educate young people about their body; Proper physical preparation is the prerequisite for successful functional assessment once young people become adults and rise in category; Remember that the results of physical fitness tests may depend on the genetic heritage and not on the training or activity proposed (Rago, V., Pizzuto, F., Raiola, G., 2017). Therefore, the purpose of this study is to recruit quantitative data (1) on anthropometric aspects and (2) the benefits to be reused to reorganize training planning. 


\section{METHODS AND MATERIALS}

\section{Subjects}

The research was carried out on a group of thirteen young people of thirteen, belonging to the football school of the A.D. Pontecagnano Academy affiliated U.C. Sampdoria. The boys are currently participating in the provincial under-14 championship, disputing their matches at the municipal stadium of Pontecagnano (SA).

\section{Experimental design}

Data were collected during 8 training sessions. First of all, the anthropometric characteristics have been identified for each boy, namely: height, weight and body mass index. The height is measured with the boy without shoes, the head oriented so that the orbital plane and the acoustic meatus are aligned horizontally. The measurement must be performed by compressing the hair while the subject breathes (Marfell et al. 2012). Starting from the systematic detection of height, projections can be made on achieving the final stature in adulthood and on the possibility of tackling early or late growth in a reliable way. (Congedo, 2009). Body mass (commonly called "weight") is measured with the subject without shoes; the instrument to be used is a scale whose calibration has been verified. The accuracy of the measurement must be $0.1 \mathrm{~kg}$ and the instrument must be placed on a rigid floor.

In young people, as regards the body mass index, it has a considerable variability mainly linked to age and sex, so also for this reason in Italy are use the percentiles proposed by Cacciari et al. in 2006. At international level, the reference parameters proposed by Cole (Cole et al., 2000) indicate as underweight a BMI lower than the 5 th percentile, normal between the 5th and the 85th, at risk of overweight between the 85th and 95th percentile and overweight the 95th percentile.

Secondly, performance data were collected using various field tests. Among the tests of resistance for young people, the Cooper test is certainly the easiest to perform, which consists in running for 12 minutes with the aim of covering the greatest distance possible. The result is the distance travelled (Cooper, 1968).It is a power test that has a relationship between the distance travelled in 12 minutes and the maximum aerobic power (expressed in Ml / kg / min) obtainable from the formula: (d12-504.9) /44.73 where $\mathrm{d} 12$ is the distance (in $\mathrm{km}$ ) travelled in 12 minutes.

The speed was analysed through the triangular (or three-corner run) test. It is part of the F-Marc 2005 battery and is indicated to investigate anaerobic resistance. The route includes a $60-\mathrm{m}$ sprint to reach a cone, where a change of direction is made to the left to reach another cone placed at $15 \mathrm{~m}$ distance. Here another change of direction is made to the left to return to the starting point, where the last change of direction is made, this time to the right, to reach the arrival line located $15 \mathrm{~m}$ away. It is an easy test to perform. Timekeeping can be done manually. It is a maximal and continuous test.

Finally, the last test is that of agility performed with the ball (Speed dribbling test). The test is performed on a specially prepared path. The player is behind the starting line and at the "start", starts to lead the ball forward for $5 \mathrm{~m}$, then performs a series of dribbles (changes of direction with various angles) around 6 cones arranged in a triangle in a space of $5 \mathrm{~m}$, then continue for another $10 \mathrm{~m}$ until reaching a cube around which it must turn, to reach - after another $8 \mathrm{~m}$ - another parallelepiped of about $2 \mathrm{~m}$ of side. Here the ball must be passed on the right (or on the left), while the player dribbles the obstacle on the other side, takes the ball and goes to a door located $20 \mathrm{~m}$, after passing it stops with his foot on the ball. The time taken is measured. 


\section{RESULTS}

Table 1. Shows the results of the anthropometric characteristics

\begin{tabular}{lccccc}
\hline & Age & Weight & Height & BMI & Percentile \\
\hline Player 1 & 13 & 87 & 1,79 & 27,1 & 97,1 \\
Player 2 & 13 & 86 & 1,81 & 26,25 & 96,3 \\
Player 3 & 13 & 62 & 1,68 & 21,9 & 85,5 \\
Player 4 & 13 & 55 & 1,65 & 20,2 & 72,6 \\
Player 5 & 13 & 79 & 1,63 & 29,73 & 98,38 \\
Player 6 & 13 & 56 & 1,68 & 19,8 & 68,8 \\
Player 7 & 13 & 68 & 1,65 & 24,98 & 94,7 \\
Player 8 & 13 & 56 & 1,52 & 24,2 & 93,3 \\
Player 9 & 13 & 53 & 1,68 & 18,8 & 54,8 \\
Player 10 & 13 & 45 & 1,48 & 20,5 & 75,8 \\
Player 11 & 13 & 64 & 1,71 & 21,9 & 85,1 \\
Player 12 & 13 & 53 & 1,68 & 18,8 & 54,8 \\
Player 13 & 13 & 54 & 1,68 & 19,1 & 59,9 \\
\hline
\end{tabular}

\begin{tabular}{cclcll}
\hline Age (13-14 Years) & Excellent & Greater than average & On average & Below average & Poor \\
\hline & $>2700 \mathrm{~m}$ & $2400-2700 \mathrm{~m}$ & $2200-2399 \mathrm{~m}$ & $2100-2199 \mathrm{~m}$ & $>2100 \mathrm{~m}$ \\
\hline
\end{tabular}

Table2. Show the Cooper test results by comparing them with the absolute reference values for the functional assessment of young people with the Cooper test

\begin{tabular}{|c|c|}
\hline Player 1 & $2182,5 \mathrm{~m}$ \\
\hline Player 2 & $2110 \mathrm{~m}$ \\
\hline Player 3 & $2080 \mathrm{~m}$ \\
\hline Player 4 & $2253,3 \mathrm{~m}$ \\
\hline Player 5 & $2127,5 \mathrm{~m}$ \\
\hline Player6 & $2209,5 \mathrm{~m}$ \\
\hline Player 7 & $2155 \mathrm{~m}$ \\
\hline Player 8 & $2297,5 \mathrm{~m}$ \\
\hline Player 9 & $2420 \mathrm{~m}$ \\
\hline Player 10 & $2230 \mathrm{~m}$ \\
\hline Player 11 & $2352,75 \mathrm{~m}$ \\
\hline Player 12 & $2380 \mathrm{~m}$ \\
\hline Player 13 & $2570 \mathrm{~m}$ \\
\hline
\end{tabular}

Table 3. Shows the results of the Speed dribbling test

\begin{tabular}{rc}
\hline & Time employee \\
\hline Player 1 & $255^{\prime 31}$ \\
Player 2 & 2744 \\
Player 3 & $26^{\prime \prime} 72$ \\
Player 4 & 28 "88 \\
Player 5 & $23^{\prime \prime 56}$ \\
\hline
\end{tabular}




\begin{tabular}{ll}
\hline Player 6 & $28 " 35$ \\
Player 7 & $25 " 97$ \\
Player 8 & $24 " 48$ \\
Player 9 & $22 " 10$ \\
Player 10 & $27 " 10$ \\
Player 11 & $25^{\prime \prime} 40$ \\
Player 12 & $23 " 10$ \\
Player 13 & $211^{\prime \prime 7}$ \\
\hline Average & $25 " 39$ \\
\hline
\end{tabular}

Table 4. Shows the results of Three Corner Run

\begin{tabular}{rc}
\hline & Time employee \\
\hline Player 1 & $29 " 10$ \\
Player 2 & $32 " 69$ \\
Player 3 & $32 " 50$ \\
Player 4 & $31 " 73$ \\
Player 5 & $38 " 75$ \\
Player 6 & $29 " 63$ \\
Player 7 & $33 " 07$ \\
Player 8 & $33 " 88$ \\
Player 9 & $31 " 25$ \\
Player 10 & $38 " 85$ \\
Player 11 & $32 " 00$ \\
Player 12 & $29 " 44$ \\
Player 13 & 28009 \\
\hline Average & $32 " 38$ \\
\hline
\end{tabular}

\section{DISCUSSION}

With regard to the data in Table 1 concerning the anthropometric characteristics, the percentiles of Cole et al (2006) were considered for the body mass index (BMI), which indicate an underweight of a BMI lower than the 5th percentile, normal between 5th and 85th, at risk of being overweight between the 85th and 95th percentile and overweight at the 95th percentile. The data shows that 6 players fall within the "right weight" range (Player 4, Player 6, Player 9, Player 10, Player 12 and Player 13), 4 are at risk of being overweight (Player 3, Player 7, Player 8 and Player 11) and finally 3 are overweight (Player 1, Player 2 and Player 5).

The results of Table 2 regarding the Cooper Test show that 2 players are in the "above average" range (Player 9 and 13), 5 players are "on average" (Player 4, Player 8, Player 10, Player11 and Player 12), 5 "below average" (Player 1, player 2, player 5, Player 6 and Player 7) and 1 "poor" (Player 3).

The results of Table 3 and Table 4 show both the time each player took for the test, and the overall average time of all players. Our data conform to the one already published in the literature by Taşkin on a study concerning the anthropometric characteristics and the speed of dribbling in Turkish players (Taşkin, 2008). 


\section{CONCLUSION}

The results have to be useful for tool method of training. They encourage to explore the links between activities and data because you have in front of you an athlete to all intents and purposes, with every pros and cons that every human being can show, even if in this case the corrections must be made in a more patient way and for the results you have to wait a little more time.

\section{REFERENCES}

Altavilla, G., Di Tore, P.A., Riela, L., D'Isanto, T. (2017). Anthropometric, physiological and performance aspects that differentiate male athletes from females and practical consequences, Journal of Physical Education and Sport, 17, 2183-2187.

Altavilla, G., Riela, L., Di Tore, A.P., Raiola, G. (2017). The physical effort required from professional football players in different playing positions. Journal of Physical Education and Sport, 17 (3), 20072012.

Altavilla, G., Gaetano, R. (2018). Physiological effects of warm-up and problems related to team sports, Sport Science, 11, 83-88.

Altavilla, G., Mazzeo, F., D'Elia, F., Raiola, G. (2018). Physical commitment and specific work for each role in an elite soccer team, Journal of Physical Education and Sport, 18 (2), 570-574.

Altavilla, G., \& Raiola, G. (2019). A brief review on physiological commitment in basketball: An interpretative key. Journal of Human Sport and Exercise, 14(1proc), S59-S65. https://doi.org/10.14198//hse.2019.14.Proc1.07

Bar-Or O, Rowland TW. Pediatric exercise medicine. Human Kinetics, Champaign III, 2004, pp 3-59).

Baur J. Allenamento e fasi sensibili. SdS, 28-29: 130-136, 1993.

Cirillo, G., Nughes, E., Acanfora, A., Altavilla, G., D'Isanto, T. (2016). Physical and sport education testing by quantitative and qualitative tools in assessment in senior school: A proposal. Sport Science, 9, 97-101.

Cole TJ, Bellizzi MC, Flegal KM, Dietz WH. (2000). Establishing a standard definition for child overweight and obesity worldwide: international survey. BMJ 320(7244): 1240-1243. https://doi.org/10.1136/bmj.320.7244.1240

Congedo P. Come classificare il grado di maturazione nei giovani. Scienza e sport 4: 66-71, 2009.

Cooper KH. (1968). A means of assessing maximal oxygen intake. JAMA 203: 201-204. https://doi.org/10.1001/jama.1968.03140030033008

D'Elia, F., Mazzeo, F., \& Raiola, G. (2018). The core curriculum in the university training of the teacher of physical education in Italy. Journal of Human Sport and Exercise, 13(2proc), S413-S420. https://doi.org/10.14198/ihse.2018.13.Proc2.25

D‘Elia, F. (2019). The training of physical education teacher in primary school. Journal of Human Sport and Exercise, 14(1proc), S100-S104. https://doi.org/10.14198/ihse.2019.14.Proc1.12

D'Isanto, T. (2016). Pedagogical value of the body and physical activity in childhood [Pedagoška vrijednost tijela i tjelesne aktivnosti u djetinjstvu]. Sport Science, 9, 13-18.

D'Isanto, T. (2019). Physical and sport education between Italian academic system and European Research Council structure panel. Journal of Human Sport and Exercise, 14, S66-S76. https://doi.org/10.14198/ihse.2019.14.Proc1.08

D'Isanto, T., D'Elia, F., Raiola, G., Altavilla, G. (2019a). Assessment of sport performance: theoretical aspects and practical indications. Sport Mont, 17(1), 79-82. https://doi.org/10.26773/smj.190214

Gaetano, R., Rago, V. (2014)Preliminary study on effects of hiit-high intensity intermittent training in youth soccer players, Journal of Physical Education and Sport, 14 (2), 148-150. 
Marella M, Risaliti M. II libro dei test. Le prove di valutazione fisica per tutti gli sport. Edizioni Correre, Milano, 1999.

Marfell-Jones MJ, Stewart AD, de Ridder JH. International standards for anthropometric assessment. Wellington, New Zealand: International Society for the Advancement of Kinanthropometry, 2012.

Myer et al. Sport Specialization, Part 1: Does Early Sports Specialization Increase Negative Outcomes and Reduce the Opportunity for Success in Young Athletes?, Sports Health, vol. $7 n^{\circ}$ 5, 2015. https://doi.org/10.1177/1941738115598747

Pincolini V. II commento del preparatore atletico. In: Roi GS, Alberti G (Eds), La preparazione atletica del calciatore dall'età evolutiva al calciatore maturo. Calzetti Mariucci Editori, Torgiano (PG), 2008, pp. 21-25.

Polidoro, L., Bianchi, F., Di Tore, P.A., Raiola, G. (2013). Futsal training by video analysis, Journal of Human Sport and Exercise, 8 (2), pp. 290-296. https://doi.org/10.4100/jhse.2012.8.Proc2.31

Rago, V., Pizzuto, F., Raiola, G. (2017). Relationship between intermittent endurance capacity and match performance according to the playing position in sub-19 professional male football players: Preliminary results. Journal of Physical Education and Sport, 17 (2), 688-691.

Raiola, G. (2013). Body knowledge and motor skills, Knowledge Cultures, 1 (6), 64-72.

Raiola, G. (2014a). Teaching method in young female team of volleyball, Journal of Physical Education and Sport, 14 (1), 74-78.

Raiola, G. (2014b). Motor control and learning skills according to cognitive and ecological dynamic approach in a vision on behaviorism, cognitive, Gestalt and phenomenology theories, Mediterranean Journal of Social Sciences, 5 (15), 504-506. https://doi.org/10.5901/mjss.2014.v5n15p504

Raiola, G., D'Isanto, T. (2016). Assessment of periodization training in soccer. Journal of Human Sport and Exercise, 11 267-278. https://doi.org/10.14198/ihse.2016.11.Proc1.19

Raiola, G., Di Tore, P.A. (2017). Motor learning in sports science: Different theoretical frameworks for different teaching methods [Motoričko učenje u sportskoj znanosti: Različiti teorijski okviri za različite metode poučavanja] Sport Science, 10, 50-56.

Raiola, G., D'Elia, F., \& Altavilla, G. (2018). Physical activity and sports sciences between European research council and academic disciplines in Italy. Journal of Human Sport and Exercise, 13(2proc), S283-S295. https://doi.org/10.14198//hse.2018.13.Proc2.13

Rago, V., Pizzuto, F., Raiola, G. (2017). Relationship between intermittent endurance capacity and match performance according to the playing position in sub-19 professional male football players: Preliminary results. Journal of Physical Education and Sport, 17 (2), 688-691.

Taşkin H. (2008). Evaluating sprinting ability, density of acceleration, and speed dribbling ability of professional soccer players with respect to their positions. J Appl Physiol 104: 542-550.

Tiziana, D., Antonetta, M., Gaetano, A. (2017). Health and physical activity [Zdravlje i tjelesna aktivnost] Sport Science, 10 (1), 100-105.

\section{@ $\odot \Theta \Theta$}

This work is licensed under a Attribution-NonCommercial-NoDerivatives 4.0 International (CC BY-NC-ND 4.0). 